\title{
The Role of Internet Addiction and Social Media Membership on University Students' Psychological Capital
}

\author{
Eylem Simsek \\ Turkish Air Forces, Turkey \\ Jale Balaban Sali \\ Anadolu University, Turkey
}

\begin{abstract}
How Internet addiction affects happiness of university students in terms of their cognitive and emotional resources was not adequately investigated. One of the inner resources of life satisfaction and happiness is defined as psychological capital (PsyCap), under the paradigm of positive psychology. PsyCap consists of four main sub-factors: hope, resilience, self-efficacy, and optimism. The major purpose of this study is to examine the role of Internet addiction and social media membership on PsyCap. The interaction between social media membership and Internet addiction was also investigated. The study employed a quantitative approach of scientific inquiry which combined descriptive, relational, and comparative models. The sample consisted of 209 students at a medium size state university in Turkey. Internet Addiction Inventory (Young, 1998) and Psychological Capital Questionnaire (Luthans et al., 2007) were employed as data gathering tools. A demographic data sheet was also used for determining the reasons and the amount of time for using Internet. In analyzing data, a set of correlation, analysis of variance, and multiple regression techniques were conducted. The results were complex. Internet addiction and PsyCap were negatively correlated. Students who spend more time on the Internet and social media, who are male and use Internet for daily communication were more likely to have higher Internet addiction scores. PsyCap can be significantly predicted by academic success, Internet addiction and having a blog. Although social media using time was not interacted with PsyCap, social media membership leaded to both higher PsyCap and higher Internet addiction. Especially, PsyCap scores of the students who had Linkedln and YouTube accounts were significantly higher. Internet addiction scores were also higher for students having Twitter, YouTube, Pinterest, and Linkedln accounts. It can be concluded that Internet addiction decreases PsyCap. Social media membership increases both Internet addiction and PsyCap.
\end{abstract}

Keywords: Internet addiction; Psychological capital; Social media; Positive psychology

\section{Introduction}

New technologies have great benefits for students regarding their education, socialization, communication etc. Many universities around the world have transformed their courses. Distance education has become much more popular. Students and instructors could easily interact with each other through social network. However, looking at the big picture, new technologies are not so innocent and flawless. They have a number of negative effects on individuals' lives. It appears that the virtual world invades the real world day by day. One of the most important consequences of the paradox between the real world and the virtual world is embodied by and observed in Internet addiction. 
Internet addiction is also called in literature as Internet addiction disorder, pathological Internet use, problematic Internet use, and compulsive Internet use. In this sense, addiction is defined as using one thing pathologically (Keser-Ozcan \& Buzlu, 2005). The concept of addiction is usually expressed in concepts like the inability to separate something and to ask for pleasure more often.

Internet addiction is an increasingly prevalent phenomenon which affects not only an individual's social but also psychological life. How Internet and social media interacts with individuals' inner resources, is not known satisfactorily. The debate on Internet addiction has been shaped within the framework of the traditional psychology and medical paradigm. Conceptualized first by Young (1996), Internet addiction was not included in the Diagnostic and Statistical Manual of Mental Disorders-Fourth Edition (DSM-IV, American Psychiatric Association, 1995), which was used for classifying psychological disorders. However, the discussions concerning the inclusion of Internet addiction in DSM $V$ classification have continued (Pies, 2009). Very similar to pathological gambling, Internet addiction was also evaluated as an impulse-control disorder, which did not involve an intoxicant like drug abuse. A brief 8-item questionnaire that depended on pathological gambling questionnaire was developed to measure the level of Internet addiction diagnosis criteria. These criteria were uncontrolled and questioned excessive Internet usage time, feeling preoccupied with the Internet, unsuccessful efforts to stop Internet use, undesired feelings about cutting down Internet use, negative effects on life, lying about Internet use, and using Internet to escape problems (Young, 1999).

Most of the features of addictions, such as salience, compulsive use (loss of control), the alleviation of distress, tolerance and withdrawal, mood modification, and the continuation despite negative consequences are growing in Internet addiction too. It is not even possible to classify Internet addiction under behavioral disorders, impulse-control disorder or obsessive compulsive disorder. Such a difficulty occurs because the symptoms of Internet addiction overlap in each of the three classifications (Cash, Rae, Steel, \& Winkler, 2012). Internet addiction could actually result from another existing disorder like depression, stress or anxiety (Young, 1999). This probability created certain doubts about the addition of Internet addiction to DSM V as a separate disorder. However, those who suggested its inclusion justified their views on the grounds that Internet addiction itself had negative impacts on the individual's life.

The present study aimed at evaluating the effects of internet addiction on psychological capital under positive psychology paradigm. More specifically, it examined whether Internet addicted students' hope, resilience, self-efficacy, and optimism scores have changed compared to the scores of non-addicted students. A possible relationship between Internet addiction and psychological capital may represent a new kind of psychological loss or gain in the digital world. In addition, how PsyCap interacts with social media membership was investigated to extend the Internet usage to Web 2.0.

\section{Internet Addiction in the Context of Positive Psychology}

At the beginning of the twenty-first century the paradigms of traditional medicine have been broken due to unmet needs of individuals including happiness and life satisfaction. The positive psychology paradigm claims that existing paradigms cannot support happiness 
requirements of individuals which should also be the main goal of science (Seligman, Steen, Park, \& Peterson, 2005).

The positive psychology paradigm, in contrast to DSM, focuses on the needs to identify and develop the strengths. Assigning Internet addiction as psychological, behavioral or psychiatric disorders is the view of conventional medicine and psychology paradigm. However, according to the positive psychology approach, Internet addiction can be evaluated as a case which prevents the individual's happiness. The immediate classification of Internet addicted individuals as patients according to the DSM template seem not a very realistic and satisfying approach for all cases. The Internet dependency of a normal individual may perhaps stem from their unhappiness, not from their psychiatric or psychological disorders. Internet addicted individuals may be those who prevent the components that make them happy via spending time on excessive or undesired Internet use. The reasons of unhappiness are generally related to lack of self-confidence, hope, interests, and relationships. Similarly, Durak-Batigun and Kilic (2011) found that Internet addiction can be successfully predicted by using the Internet for social interaction, having low life satisfaction levels and low self-control scores in addition to having higher neuroticism, anxiety, and somatization scores.

Probably, one of the major reasons behind the classification of Internet use as an addiction is the sense of disorder created by the Internet. Unhappiness, declining performance and health problems may all be associated with Internet addiction (Sally, 2006). As pathological Internet use increased, adolescent students have significantly lower grade point averages (GPA) (Bayraktar \& Gun, 2007). Academic, interpersonal, and physical problems are all found to be correlated with Internet addiction (Ozcinar, 2011). Excessive and inappropriate uses of Internet of university students or adolescents is connected with depression (Orsal, Orsal, Unsal, \& Ozalp, 2012), anxiety (Azher et al., 2014), stress (Akin \& Iskender, 2011), obesity, psychosomatic symptoms (Cao et al., 2011), suicidal ideation (Kim et al., 2011), mental health problems (Xiuqin et al., 2010), loneliness (Eroglu, Pamuk, \& Pamuk, 2013), divorce, child neglect (Young, 1998). Reducing all these factors into a single factor, one comes across with unhappiness. Young and Rogers (1997) claimed that Internet addiction is a result of some psychological problems. As a psychological escape mechanism, Internet helps avoid problems or perceived personal beliefs such as low self-esteem and worth.

Authentic happiness theory of Seligman (2007) is based on pleasure, engaged and meaningful life experiences. Achieving happiness is entirely based on the balance of these three elements. Pleasure is found to have minimum effect on happiness compared to engagement and meaning. Happiness is discovered as a result of the experience of signature powers and virtues. Individuals can be as happy as they could use their strengths and virtues. Instead of experiencing more meaningful activities or flow, individuals spend too much time on the Internet, and satisfy pleasure needs. This causes neglecting family, job, reluctance of the flow activities, fatigue, deterioration of interpersonal relationships (Young, 1999). Therefore, the individual may not reveal his/her true power which is one of the significant predictors of happiness. Internet addiction leads to decrease in all of these power using experiences causing unhappiness.

It should also be investigated how Internet addiction affects the happiness of individuals in terms of emotional and cognitive processes. Pleasures have a critical role on an individual's life. Internet use is known to cause a sense of reward (O'Brien, 2010) which forms the basis for all kinds of addiction. Among various Internet usage reasons, typically Internet addicts use Internet for entertainment, interaction, and satisfaction (Yang \& Tung, 2004). In the short 
term, addictions provide fulfillment of the requirements such as artificial/temporary feeling of security or calm, self-worth or accomplishment, power or control, intimacy or belonging. Internet addiction is accepted as a way to escape from problems in the short term, whereas the issues left drag on largely (Young, 1999). It is not known whether Internet addiction has an effect on activating inner resources, strengths, and power.

\section{Psychological Capital (PsyCap)}

PsyCap has been accepted as one of the inner resources of life satisfaction and happiness under the paradigm of positive psychology. PsyCap consists of four main sub-factors: hope, resilience, self-efficacy, and optimism (Luthans \& Youssef, 2004). These concepts are detailed as (1) having confidence (self-efficacy) to take on and put in the effort to succeed at challenging tasks necessary; (2) making a positive attribution (optimism) about succeeding now and in the future; ( 3 ) persevering toward goals and, when necessary, redirecting paths to goals (hope) in order to succeed; and (4) when beset by problems and adversity, sustaining and bouncing back and even beyond (resilience) to attain success (Luthans, Youssef, \& Avolio, 2007, p.3). All of these concepts are related to each other, but psychological resilience cover others more (Cetin \& Basim, 2011).

The PsyCap approach suggests that individuals should be resistant, hopeful, optimistic, and self confident against problems. PsyCap strengthening is defined as developing and supporting the positive attributes to cope with the psychological problems, to find new ways for the solution of the problems, not to escape from the problems. In the context of escape and Internet addiction as well as all the other types of addiction, provide a virtual state of well-being and strength. However, in reality, deterioration of relations, indifference, failure etc. weakens the individual. PsyCap has a developmental structure, requiring time and energy investment (Csikszentmihalyi \& Nakamura, 2009). When individual's time and energy expenditures of the Internet increase, he/she consumes the internal mechanisms, needed for coping with challenges and for being happy.

The level of individual's maintained happiness is specified like a thermostat (Chen \& Davey, 2009; Cummins, 2000). Sometimes excessive or improper use of the Internet may significantly damage the individual's inner systems. At that point it can be claimed that the inner thermostat is impaired, and Internet addiction may be defined as pathological problems. Longterm Internet addiction may produce structural alterations in brain (Yuan et al., 2011), which can be associated with the damaged happiness mechanism.

The predictors of Internet addiction are indicated by Young and Rogers (1997) as Internet using time, the reason of Internet usage, and some personality traits. They determine Internet addicts' profiles according to 16PF. Dependents rank themselves high in terms of self-reliance, emotional sensitivity and reactivity, vigilance, low self-disclosure, and non-conformist characteristics.

Personality strengths and virtues are usually considered trait-like, which means mostly stable. (Eynseck, 1995; Seligman, Steen, Park, \& Peterson, 2005). However, the concept of PsyCap is classified as state-like, implying not stable, open to change and development (Luthans, Avolio, Avey, \& Norman, 2007). State-like did not mean momentary. Within the framework of Internet addiction, the state-like feature of PsyCap enables to question whether strengthening PsyCap prevents Internet addiction or whether Internet-addicted and not-addicted are significantly 
different in terms of PsyCap. From this point, the current study aimed to investigate the relationship between Internet addiction and mechanisms of individual happiness through PsyCap.

Internet addiction, which affects an individual's life, may be caused by some life problems. Determination of the PsyCap's positive effects on individuals' life may lead to more focus on the state-like approaches, permitting to develop and strengthen. The literature reports no study that investigated the relationship between PsyCap and Internet addiction. Besides the internet addiction, the role of social media membership on the inner psychological resources is not known either. Therefore, this study is expected to contribute to the existing literature by enlightening the psychological results of students' Internet and social media experiences.

The main purpose of the present study is to investigate the role of Internet addiction on PsyCap concerning some demographic variables and social media membership. Toward this purpose, answers are sought to the following questions:

1. What are the levels of students' Internet addiction and PsyCap?

2. Are there any significant differences in Internet addiction and PsyCap, when personal data and social media membership are considered?

3. What is the correlation between Internet addiction and PsyCap?

4. Are the any significant differences in PsyCap when Internet-addicted and not-addicted students are compared?

5. How much of the PsyCap is explained by personal variables, social media membership, and Internet addiction?

\section{Methods}

\section{Model}

The study employed a quantitative approach of scientific inquiry which combined descriptive, relational, and comparative models to explore the interactions between personal variables, Internet addiction, and PsyCap. The model is illustrated in Figure1.

\section{Personal Data}

- Gender, economic status, class, academic success, Internet using time, connection from house/dormitory or cell phone, the aim of Internet use, time spending on social media, having a blog or not.

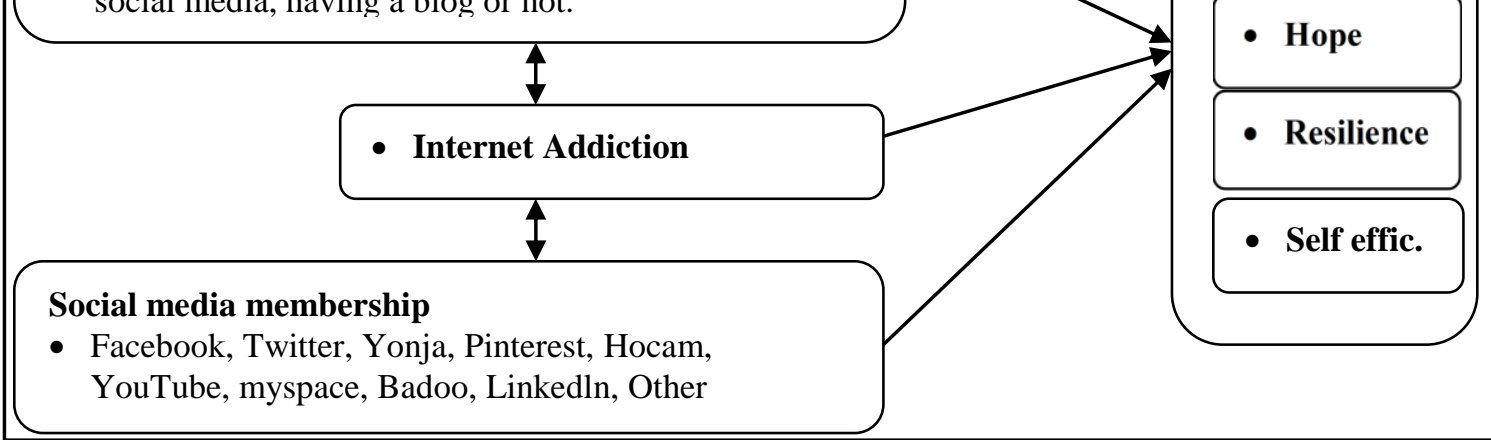

Figure 1. Research Model 


\section{Sample}

The data in the present study were collected from 211 university students in Faculty of Communication Sciences, Anadolu University, Turkey. After initial checks, 2 cases were deleted because of being univariate outliers. Thus, data from 209 (94 female and 115 male) students were analyzed. Descriptive statistics of the personal data are presented in Table 1.

Table 1. Descriptive Statistics of Demographic Information and Social Media Membership

\begin{tabular}{|c|c|c|c|c|c|}
\hline Independent Variable & $\mathbf{N}$ & $\%$ & Independent Variable & $\mathbf{N}$ & $\%$ \\
\hline \multicolumn{3}{|l|}{ 1.Gender } & \multicolumn{3}{|l|}{ 9.Facebook Membership } \\
\hline Female & 94 & 45 & Yes & 204 & 97,6 \\
\hline Male & 115 & 55 & No & 5 & 2,4 \\
\hline \multicolumn{3}{|l|}{ 2. Class } & \multicolumn{3}{|l|}{ 10. Twitter Membership } \\
\hline 2 & 94 & 45 & Yes & 171 & 81,8 \\
\hline 3 & 31 & 15 & No & 38 & 18,2 \\
\hline 4 & 84 & 40 & \multicolumn{3}{|l|}{ 11. Yonja Membership } \\
\hline \multicolumn{3}{|l|}{ 3. Economic status } & Yes & 3 & 2 \\
\hline Low & 25 & 12 & No & 206 & 98 \\
\hline Middle & 172 & 82 & \multicolumn{3}{|l|}{ 12. Pinterest Membership } \\
\hline High & 12 & 6 & Yes & 29 & 14 \\
\hline \multicolumn{3}{|l|}{ 4. Academic success } & No & 180 & 86 \\
\hline Low & 14 & 7 & \multicolumn{3}{|l|}{ 13. Hocam Membership } \\
\hline Middle & 133 & 63 & Yes & 16 & 8 \\
\hline High & 62 & 30 & No & 193 & 92 \\
\hline \multicolumn{3}{|l|}{ 5. Internet use time } & \multicolumn{3}{|l|}{ 14. YouTube Membership } \\
\hline $0-2$ hour & 55 & 26 & Yes & 123 & 59 \\
\hline 2-3 hour & 92 & 44 & No & 86 & 41 \\
\hline 3 and more & 62 & 30 & \multicolumn{3}{|l|}{ 15. MySpace Membership } \\
\hline \multicolumn{3}{|l|}{ 6. Connected from } & Yes & 26 & 13 \\
\hline House/dormitory & 186 & 89,0 & No & 183 & 87 \\
\hline Cell phone & 23 & 11,0 & \multicolumn{3}{|l|}{ 16. Bado Membership } \\
\hline \multicolumn{3}{|l|}{ 7. Aim } & Yes & 4 & 2 \\
\hline Communication & 81 & 38,8 & No & 205 & 98 \\
\hline Research & 19 & 9,1 & \multicolumn{3}{|l|}{ 17. LinkedIn Membership } \\
\hline Entertainment/News & 24 & 11,5 & Yes & 81 & 39 \\
\hline Social media & 70 & 33,5 & No & 128 & 61 \\
\hline Film & 15 & 7,2 & \multicolumn{3}{|l|}{ 18. Other Membership } \\
\hline \multicolumn{3}{|c|}{ 8. Time spent on social media daily } & Yes & 14 & 7 \\
\hline $0-1$ hours & 41 & 19,6 & No & 195 & 93 \\
\hline 1-2 hours & 90 & 43,1 & \multicolumn{3}{|l|}{ 19. Category of Internet addiction } \\
\hline $2-3$ hours & 52 & 24,9 & Not addicted & 101 & 48 \\
\hline 4 hours and more & 26 & 12,4 & Addicted & 108 & 52 \\
\hline
\end{tabular}

\section{Instruments}

Demographic Data Form: It included items about gender, economic status, class, academic success, Internet using time, connection from house/dormitory or cell phone, the aim of Internet use, time spending on social media, having a blog or not. Moreover, the types of social media accounts were asked. Facebook, Twitter, Yonja, Pinterest, Hocam, YouTube, MySpace, Badoo, and Linkedln memberships were determined.

Internet Addiction Inventory (Young, 1998): Internet Addiction Inventory was developed according to the DSM-IV pathological gambling criteria by Young (1998). It had 20 questions measuring one higher factor. The scale was a 5 point Likert type scale. The original scale 
suggested categorizing 70-100 points as addicted, 40-69 points as probably addicted, 39 and lower as not addicted. It was translated into Turkish by Bayraktar (2001) with the Cronbach alpha of 0.91 . The Cronbach alpha value in the present study was .88 for university students. Two categories were found more appropriate than four categories, which are categorized as Internet-addicted or not-Internet-addicted.

Psychological Capital Questionnaire (Luthans et al., 2007): PsyCap questionnaire was developed originally by Luthans et al. (2007) for organizations. Cetin and Basim (2012) translated the PsyCap Questionnaire into Turkish with the .91 of Cronbach alpha value. An adaptation was made to measure the students PsyCap in this study. PsyCap had four subfactors: hope, resilience, optimism, and self-efficacy. Here 6 questions for each sub-factor were asked. PsyCap Questionnaire consisted of totally 24 items with a 6-point scale each. The results were recorded into 0-100 range. The Cronbach alpha value was calculated as .90 in this study.

Procedures: The questionnaires were filled by the students in the Faculty of Communication Sciences, Anadolu University. Data analyses were conducted using SPSS. Correlations between the variables were evaluated using Pearson Correlation procedure. Variance analyses tested whether the mean differences in demographic data, social media membership, and Internet addiction categories would be associated with significant differences in PsyCap scores. Regression analyses outcomes enlightened the causal relationship and the explained variance by independent variables in both PsyCap and Internet addiction. The results were discussed in context of the related literature.

\section{Results}

Independent variables of this study were demographic information, social media membership, Internet addiction, whereas dependent variables were PsyCap and its sub-factors (optimism, hope, resilience, and self-efficacy). Descriptive statistics of the Internet addiction and PsyCap are illustrated in Table 2.

The lowest mean scores for PsyCap is optimism scores $(M=63.82, S D=10.89)$ and the highest one is self-efficacy scores $(M=74.83, S D=15.66)$. The mean of the Internet addiction $(M=44.94$, $\mathrm{SD}=11.47$ ) is evaluated as "probably addicted" according to Young's (1998) criteria.

Table 2. Descriptive Statistics of Internet Addiction and PsyCap

\begin{tabular}{llllll}
\hline & N & Min & Max & Mean & SD \\
\hline Internet addic. & 209 & 23,33 & 84,17 & 44,94 & 11,47 \\
PsyCap & 209 & 36,11 & 97,92 & 71,25 & 11,25 \\
Optimism & 209 & 33,33 & 94,44 & 63,82 & 10,89 \\
Resilience & 209 & 38,89 & 100,00 & 74,43 & 13,49 \\
Hope & 209 & 27,78 & 100,00 & 71,92 & 13,52 \\
Self efficacy & 209 & 27,78 & 100,00 & 74,83 & 15,66 \\
\hline
\end{tabular}

Demographic data were analyzed in terms of Internet addiction and PsyCap scores. The means and SD's for each group are presented on Table 3. The mean differences were tested by a set of variance analyses. Internet addiction means are significantly different in terms of Internet using time $[F(2,206)=19.9, p<.001]$, aim of Internet use $[F(4,204)=2.99, p<.05]$ and social 
media using time $[F(3,205)=10,57, p<.001]$. As Internet and social media using time increase, Internet addiction scores increase.

Additionally, students' using Internet for communication are more likely to develop an Internet addiction than those using Internet for entertainment/news. PsyCap means differ significantly, when academic success levels $[F(2,206)=8.6, p<.001]$, connection from house/dormitory or cell phone $[F(1,207)=5.7, p<.05]$ and having a blog or not $[F(1,207)=4.60, p<.05]$ criteria are compared.

Table 3. Means of Internet Addiction and PsyCap and Mean Differences for Personal Data

\begin{tabular}{|c|c|c|c|c|c|c|c|c|}
\hline \multirow[b]{2}{*}{ IV } & \multirow[t]{2}{*}{ DV } & \multirow[b]{2}{*}{$\mathbf{N}$} & \multicolumn{3}{|c|}{ Internet Addiction } & \multicolumn{3}{|l|}{ PsyCap } \\
\hline & & & Mean & SD & Sig/F & Mean & SD & Sig/F \\
\hline \multirow{2}{*}{ Gender } & Female & 94 & 43,49 & 10,99 & \multirow{2}{*}{ Not significant } & 72,08 & 11,95 & \multirow{2}{*}{ Not significant } \\
\hline & Male & 115 & 46,12 & 11,77 & & 70,57 & 10,65 & \\
\hline \multirow{3}{*}{ Class } & 2 & 94 & 44,31 & 12,35 & \multirow{3}{*}{ Not significant } & 70,14 & 11,08 & \multirow{3}{*}{ Not significant } \\
\hline & 3 & 31 & 41,77 & 9,40 & & 70,29 & 12,42 & \\
\hline & 4 & 84 & 46,81 & 10,92 & & 72,85 & 10,94 & \\
\hline \multirow{3}{*}{ Eco Status } & Low & 25 & 45,46 & 10,87 & \multirow{3}{*}{ Not significant } & 67,27 & 12,31 & \multirow{3}{*}{ Not significant } \\
\hline & Middle & 172 & 44,57 & 11,28 & & 71,64 & 11,07 & \\
\hline & High & 12 & 49,10 & 15,22 & & 73,90 & 10,70 & \\
\hline \multirow{3}{*}{ Academic success } & Low & 14 & 46,02 & 11,25 & \multirow{3}{*}{ Not significant } & $63,73^{*}$ & 9,00 & \multirow{3}{*}{$\begin{array}{l}F(2,206)= \\
8.6 \\
p<.001\end{array}$} \\
\hline & Middle & 133 & 44,15 & 11,04 & & $70,11^{*}$ & 11,59 & \\
\hline & High & 62 & 46,39 & 12,42 & & $75,40 *$ & 9,53 & \\
\hline \multirow{3}{*}{ Internet use time } & $0-2$ hour & 55 & $38,49 *$ & 9,78 & \multirow{3}{*}{$\begin{array}{l}F(2,206)= \\
19.9 \\
p<.001\end{array}$} & 71,29 & 11,29 & \multirow{3}{*}{ Not significant } \\
\hline & $2-3$ hour & 92 & $44,83^{*}$ & 10,29 & & 71,14 & 11,18 & \\
\hline & 3 and more & 62 & $50,82 *$ & 11,55 & & 71,37 & 11,51 & \\
\hline \multirow[b]{2}{*}{ Connected from } & House/dor. & 186 & 45,28 & 11,43 & \multirow[b]{2}{*}{ Not significant } & $70,64^{*}$ & 11,01 & \multirow{2}{*}{$\begin{array}{l}F(1,207)= \\
5.07 \\
p<.05\end{array}$} \\
\hline & Cell phone & 23 & 42,18 & 11,69 & & $76,19 *$ & 12,21 & \\
\hline \multirow{5}{*}{ Aim } & Commun. & 81 & $47,38^{*}$ & 11,70 & \multirow{5}{*}{$\begin{array}{l}F(4,204)= \\
2,99 \\
p<.05\end{array}$} & 71,62 & 10,37 & \multirow{5}{*}{ Not significant } \\
\hline & Research & 19 & 41,73 & 13,24 & & 68,46 & 10,90 & \\
\hline & Ent/news & 24 & $39,31^{*}$ & 9,29 & & 68,02 & 13,76 & \\
\hline & Social med. & 70 & 44,48 & 10,99 & & 72,98 & 11,57 & \\
\hline & Film & 15 & 47,00 & 10,16 & & 69,86 & 9,87 & \\
\hline \multirow{4}{*}{$\begin{array}{l}\text { Social media using } \\
\text { time }\end{array}$} & $0-1$ hours & 41 & $37,22^{*}$ & 10,14 & \multirow{4}{*}{$\begin{array}{l}F(3,205)= \\
10,57 \\
p<.001\end{array}$} & 72,63 & 12,51 & \multirow{4}{*}{ Not significant } \\
\hline & 1-2 hours & 90 & 45,46 & 10,82 & & 70,67 & 10,28 & \\
\hline & 2-3 hours* & 52 & $47,07^{*}$ & 11,55 & & 71,17 & 11,05 & \\
\hline & 4 hours-more & 26 & 51,028 & 9,76 & & 71,26 & 13,20 & \\
\hline \multirow[b]{2}{*}{ Having a blog } & Yes & 55 & 47,03 & 10,92 & & $74,02 *$ & 10,05 & $F(1,207)=$ \\
\hline & No & 154 & 44,19 & 11,61 & Not significant & $70,26 *$ & 11,52 & $\begin{array}{l}4.60 \\
p<.05\end{array}$ \\
\hline
\end{tabular}

*Represents significant mean differences between variables

The interactions of social media membership with Internet addiction and PsyCap were tested by a series of variance analyses. The results, which are remarkable, are summarized in Table 4. Almost all types of social media membership, in other words having an account, led to a trend of higher Internet addiction means and higher PsyCap means. The mean differences were tested using one-way ANOVA, assigning social media membership as independent variable. Students, having Twitter, YouTube, and Pinterest account have significantly higher Internet addiction scores than those not having these account. In addition, PsyCap significantly differ depending on the membership status of YouTube and Linkedln. YouTube and Linkedln members' PsyCap are significantly higher. These results explain that Internet addiction and PsyCap increases for those who are social media members. 
Table 4. Internet Addiction and PsyCap Mean Differences Based on Social Media Membership

\begin{tabular}{|c|c|c|c|c|c|c|c|c|}
\hline \multirow[b]{2}{*}{ IV } & \multirow{2}{*}{$\begin{array}{l}\text { DV } \\
\text { Have an } \\
\text { account }\end{array}$} & \multirow[b]{2}{*}{$\mathbf{N}$} & \multicolumn{3}{|c|}{ Internet Addiction } & \multicolumn{3}{|l|}{ PsyCap } \\
\hline & & & Mean & SD & $\mathrm{Sig} / \mathrm{F}$ & Mean & SD & $\mathrm{Sig} / \mathrm{F}$ \\
\hline \multirow{2}{*}{ Facebook } & Yes & 204 & 45,21 & 11,18 & \multirow{2}{*}{ Not tested } & 71,37 & 11,18 & \multirow{2}{*}{ Not tested } \\
\hline & No & 5 & 33,83 & 18,47 & & 66,39 & 14,46 & \\
\hline \multirow{2}{*}{ Twitter } & Yes & 171 & $45,96^{*}$ & 11,03 & \multirow{2}{*}{$\begin{array}{l}F(1,207)= \\
7,73 \\
p<.01\end{array}$} & 71,76 & 11,34 & \multirow{2}{*}{$\begin{array}{l}\text { Not } \\
\text { significant }\end{array}$} \\
\hline & No & 38 & $40,33^{*}$ & 12,42 & & 68,93 & 10,68 & \\
\hline \multirow{2}{*}{ YouTube } & Yes & 171 & $46,81^{*}$ & 11,84 & \multirow{2}{*}{$\begin{array}{l}F(1,207)= \\
8,22 \\
p<.005\end{array}$} & $72,63^{*}$ & 10,80 & \multirow{2}{*}{$\begin{array}{l}F(1,207)= \\
4,54 \\
p<.05\end{array}$} \\
\hline & No & 38 & $42,26^{*}$ & 10,41 & & $69,28 *$ & 11,66 & \\
\hline \multirow{2}{*}{ Pinterest } & Yes & 123 & $50,35 *$ & 11,33 & \multirow{2}{*}{$\begin{array}{l}F(1,207)= \\
7,74 \\
p<.01\end{array}$} & 73,83 & 10,12 & \multirow{2}{*}{$\begin{array}{l}\text { Not } \\
\text { significant }\end{array}$} \\
\hline & No & 86 & $44,07^{*}$ & 11,28 & & 70,83 & 11,40 & \\
\hline \multirow{2}{*}{ MySpace } & Yes & 26 & 47,57 & 13,73 & \multirow{2}{*}{$\begin{array}{l}\text { Not } \\
\text { significant }\end{array}$} & 73,18 & 11,71 & \multirow{2}{*}{$\begin{array}{l}\text { Not } \\
\text { significant }\end{array}$} \\
\hline & No & 183 & 44,56 & 11,11 & & 70,98 & 11,20 & \\
\hline \multirow{2}{*}{ Linkedln } & Yes & 81 & $48,58^{*}$ & 11,10 & \multirow{2}{*}{$\begin{array}{l}F(1,207)= \\
14,19 \\
p<.001\end{array}$} & $73,25 *$ & 10,23 & \multirow{2}{*}{$\begin{array}{l}F(1,207)= \\
4,26 \\
p<.05\end{array}$} \\
\hline & No & 128 & $42,63 *$ & 11,14 & & $69,98^{*}$ & 11,72 & \\
\hline \multirow{2}{*}{ Hocam } & Yes & 16 & 47,43 & 9,56 & \multirow{2}{*}{$\begin{array}{l}\text { Not } \\
\text { significant }\end{array}$} & 74,39 & 12,91 & \multirow{2}{*}{$\begin{array}{l}\text { Not } \\
\text { significant }\end{array}$} \\
\hline & No & 193 & 44,73 & 11,61 & & 70,99 & 11,10 & \\
\hline \multirow{2}{*}{ Badoo } & Yes & 4 & 51,46 & 6,40 & \multirow{2}{*}{ Not tested } & 75,00 & 14,93 & \multirow{2}{*}{ Not tested } \\
\hline & No & 205 & 44,81 & 11,52 & & 71,18 & 11,21 & \\
\hline \multirow{2}{*}{ Yonja } & Yes & 3 & 49,17 & 7,95 & \multirow{2}{*}{ Not tested } & 79,17 & 12,52 & \multirow{2}{*}{ Not tested } \\
\hline & No & 206 & 44,88 & 11,52 & & 71,13 & 11,23 & \\
\hline
\end{tabular}

Bivariate Pearson correlation coefficients and correlation matrixes were analyzed in order to identify the relationship between Internet addiction and PsyCap. As presented in Table 5, only Internet addiction and resilience are found negatively and significantly correlated $(r=-.14, p<$ .01). As Internet addiction increases, resilience of the individual decreases.

Table 5. The Correlations between Internet Addiction and PsyCap

\begin{tabular}{lllllll}
\hline & Opt. & Res. & Hope & Self effic. & PsyCap & Int. Add. \\
\hline Optimism & 1 & & & & & \\
Resilience &, $446^{* *}$ & 1 & & & & \\
Hope &, $530^{* *}$ &, $719^{* *}$ & 1 & & & \\
Self-efficacy &, $446^{* *}$ &, $681^{* *}$ &, $728^{* *}$ & 1 & & \\
PsyCap &, $690^{* *}$ &, $860^{* *}$ &, $897^{* *}$ &, $879^{* *}$ & 1 & \\
Int. Addiction &, 002 &,$- 139^{*}$ &,- 036 &,- 072 &,- 077 & 1 \\
\hline
\end{tabular}

** Correlation is significant at the 0.01 level (2-tailed).

* Correlation is significant at the 0.05 level (2-tailed).

\section{Categorized Internet Addiction}

A set of ANOVA was conducted to test whether PsyCap scores might change, when Internet addiction levels differ in accordance with the major purpose of this study. First, Internet addiction scores were grouped into four categories using SPSS categorization criteria in accordance with means and SD's (M=44.94, SD=11.47) of Internet addiction. The means of the PsyCap's depending on the four Internet addiction categories are presented in Table 6. A trend can be seen; as the mean scores of Internet addiction increase, lower PsyCap means are observed. The mean differences were compared using analysis of variance. No significant 
differences were found between the means of PsyCap according to Internet addiction groups $[F(3,205)=1.30, p=.276]$.

Table 6. Mean and SD's According to the Four Internet Addiction Categories

\begin{tabular}{lllllll}
\hline & & \multicolumn{2}{c}{ Internet addiction } & \multicolumn{2}{c}{ PsyCap } \\
\hline Internet Addic. & R of Int. Add. & N & M & SD & M & SD \\
\hline Category 1 & $23.3-36.0$ & 53 & 31,35 & 3,64 & 72,85 & 11,55 \\
Category 2 & $36.1-44.2$ & 48 & 40,02 & 2,13 & 72,72 & 10,54 \\
Category 3 & $44.3-52.5$ & 56 & 47,64 & 2,58 & 69,31 & 10,42 \\
Category 4 & $52.6-84.2$ & 52 & 60,41 & 6,72 & 70,35 & 12,31 \\
Total & $23.3-84.2$ & 209 & 44.94 & 11.47 & 71,25 & 11,25 \\
\hline
\end{tabular}

Internet addiction scores were grouped into two categories using SPSS categorization criteria, namely not-Internet-addicted (category 1 ) and Internet-addicted (category 2 ). The range of the not-Internet-addicted students is $23.3-44.2$, whereas the range for Internet addicted students is 44.3-84.2 based on the 100 points of Internet Addiction scale. Addicted ( $N=101)$ and notaddicted $(\mathrm{N}=108)$ students' PsyCap mean differences were tested by analysis of variance. The results of the analysis of variance are significant $[F(1,207)=3.69, p<.005]$. The PsyCap of Internet addicted students $(M=72.79, S D=11.03)$ are significantly lower than not-Internetaddicted students ( $M=69.8, S D=11.33)$. In other words, Internet addicted students have poorer PsyCap (Table 7).

Table 7. Means and SD's of PsyCap According to the Two Internet Addiction Categories

\begin{tabular}{lllllll}
\hline & & \multicolumn{2}{c}{ Internet Addiction } & \multicolumn{2}{c}{ PsyCap } \\
& R of Int. Add. & N & M & SD & M & SD \\
\hline Category 1 & $23,3-44,2$ & 101 & 35,47 & 5,29 & $72,79 *$ & 11,03 \\
Category 2 & $44,3-84,2$ & 108 & 53.79 & 8.13 & $69,81^{*}$ & 11,33 \\
Total & $23,3-84,2$ & 209 & 44.94 & 11.47 & 71,25 & 11,25 \\
\hline
\end{tabular}

*Significant mean differences at the .005 level

Whether the sub-factors of PsyCap (hope, resilience, optimism, and self-efficacy) may be associated with the differences between Internet-addicted and not-Internet-addicted groups was examined. Means and SD's of PsyCap subcategories are presented in Table 8.

Table 8. Means and SD's of PsyCap Sub-factors According to Internet Addiction Categories

\begin{tabular}{lllllll}
\hline & \multicolumn{3}{c}{ Not Internet addicted } & \multicolumn{3}{c}{ Internet addicted } \\
& N & M & SD & N & M & SD \\
\hline Optimism & 101 & 64,08 & 11,55 & 108 & 63,57 & 10,27 \\
Resilience* & 101 & 76,71 & 13,38 & 108 & 72,29 & 13,30 \\
Hope & 101 & 73,17 & 12,63 & 108 & 70,76 & 14,26 \\
Self-efficacy * & 101 & 77,18 & 15,53 & 108 & 72,64 & 15,54 \\
\hline
\end{tabular}

*Significant mean differences at the .05 level

Of the four PsyCap sub-categories, the mean values for resilience $[F(1,207)=5.73, p<.05]$ and self-efficacy $[F(1,207)=4.46, p<.05]$ of Internet-addicted and not-addicted students are significantly different. Optimism and hope means of Internet-addicted students are lower than 
not-Internet-addicted students, although the difference is not statistically significant. If students were Internet-addicted, they possess less resilience and self-efficacy compared to not-Internet-addicted ones.

\section{The Predictors of PsyCap}

The causality between demographic variables, social media membership, Internet addiction, and PsyCap were tested using regression analyses. A series of regression analyses were conducted assigning PsyCap as dependent variable. In order to predict PsyCap total score, demographic information and Internet addiction with two categories were regressed onto PsyCap total scores using stepwise criterion. Regression results are given in Table 9.

Internet addiction is a significant predictor of PsyCap, resilience, and self-efficacy. The explained variances uniquely by Internet addiction on PsyCap (\%2), on resilience (\%2.7) and on self-efficacy (\%2.4) are not very high but significant. In general, as Internet addiction increases, PsyCap decreases.

PsyCap was predicted significantly by Internet addiction, academic success, having a blog and an Internet connection. All these variables explain 13.3\% of variance in PsyCap. The students, with higher academic success, have a blog, not-Internet-addicted, connected with cell phone to Internet are more likely to possess higher PsyCap scores. Connecting to the Internet with cell phone can be seen a sign of something else (such as using Internet less), implying that being not-Internet-addicted.

Internet addiction and having a blog explain together $4.7 \%$ variance of resilience. Academic success and Internet addiction affect self-efficacy significantly, explaining $8.6 \%$ variance. Optimism can be significantly predicted by academic success and gender, explaining $7.6 \%$ variance. More successful and female students are most likely to have higher optimism scores. Similarly, academic success is a predictor of hope, explaining $11.2 \%$ variance.

Table 9. Regression Table (IV's: Personal Data, Internet Addiction Categories; DV's: PsyCap Total and Four Subcategories Separately)

\begin{tabular}{|c|c|c|c|c|c|}
\hline $\begin{array}{l}\text { Dependent } \\
\text { Variables }\end{array}$ & \multicolumn{2}{|r|}{ Predictor(Uniqe $\mathbf{R}^{2}$ ) } & Beta & $\mathbf{t}$ & Sig. \\
\hline \multirow{5}{*}{ 1. PsyCap Total } & $x 1$ & Academic success $\left(\mathbf{R}^{\mathbf{2}}=\mathbf{. 0 7 7}\right)$ & ,26 & 3,97 & , 000 \\
\hline & $x 2$ & Internet addiction $\left(\mathbf{R}^{2}=.020\right)$ &,- 15 & $-2,22$ & 028 \\
\hline & $x 3$ & Having a blog $\left(\mathbf{R}^{2}=.020\right)$ &,- 14 & $-2,15$ & 032 \\
\hline & $x 4$ & Internet connection $\left(\mathbf{R}^{\mathbf{2}}=\mathbf{. 0 1 7}\right)$ & 13 & 2,01 & 045 \\
\hline & \multicolumn{5}{|c|}{$\mathrm{R}=.364, \mathrm{R}^{2}=.133, \mathrm{~F}(4,204)=7.80, \mathrm{p}<.001$} \\
\hline \multirow{3}{*}{ 2. Optimism } & $\mathrm{x} 1$ & Academic success $\left(\mathbf{R}^{2}=.058\right)$ & ,23 & 3,46 & 001 \\
\hline & $x 2$ & Gender $\left(\mathbf{R}^{2}=. \mathbf{0 1 2}\right)$ &,- 14 & $-2,05$ & 042 \\
\hline & \multicolumn{5}{|c|}{$R=, 276, R^{2}=.076, F(2,206)=8.53, p \leq .001$} \\
\hline \multirow{3}{*}{ 3. Resilience } & $\mathrm{X} 1$ & Internet addiction $\left(\mathbf{R}^{2}=.027\right)$ &,- 18 & $-2,57$ & 011 \\
\hline & $\mathrm{X} 2$ & Having a blog $\left(\mathbf{R}^{2}=.020\right)$ &,- 14 & $-2,08$ & 038 \\
\hline & \multicolumn{5}{|c|}{$R=, 217, R^{2}=.047, F(2,206)=5.079, p \leq .01$} \\
\hline \multirow{2}{*}{ 4. Hope } & $\mathrm{x}$ & Academic success $\left(R^{2}=.112\right)$ &,- 33 & 5,11 &, 000 \\
\hline & \multicolumn{5}{|c|}{$R=, 334, R^{2}=.112, F(1,207)=26,06, p<.001$} \\
\hline \multirow{3}{*}{ 4. Self-efficacy } & $\mathrm{X} 1$ & Academic success $\left(\mathbf{R}^{2}=.062\right)$ & ,26 & 3,8 & , 000 \\
\hline & $\mathrm{X} 2$ & Internet addiction $\left(\mathbf{R}^{2}=.024\right)$ &,- 16 & $-2,32$ & 021 \\
\hline & \multicolumn{5}{|c|}{$R=, 293, R^{2}=, 086, F(2,206)=9.67, p<.001$} \\
\hline
\end{tabular}


Another regression analysis was run assigning the type of social media as an independent variable. YouTube is the only technology that significantly predicted PsyCap. The variance explained by YouTube membership on PsyCap is $2.1 \%$. [ $F(1,207)=4.54$, Beta=-.147, $t=-2.13$, $p<.05]$. Among the social media types, Linkedln members have significantly higher hope scores $[F(1,207)=7.05$, Beta $=-.18, t=-2.66, p<.01]$. The explained variance by Linkedln membership on hope is 3.3\%. YouTube members are more resilient $[F(1,207)=4.95$, Beta=--.15, $t=-2.22$, $p<.05]$ and have higher self efficacy $[F(1,207)=5.33$, Beta=-.16, $t=--2.31, p<.05]$. YouTube explain $2.5 \%$ of resilience and $2.3 \%$ of self-efficacy.

When all these stepwise regression results are summarized, students who are academically more successful, had a blog, female, and not-Internet-addicted, had YouTube or Linkedln accounts are more likely to be richer in PsyCap or its sub-factors.

\section{The Predictors of Internet Addiction}

The predictors of Internet addiction were determined using stepwise regression. Internet addiction was assigned as dependent variable. First, demographic data were regressed on Internet addiction. Of the demographic data, the time spending on Internet is the most powerful predictor of Internet addiction. It explains $16.2 \%$ of the total variance in Internet addiction. Time spent on social media explains $2.1 \%$ of the variance in Internet addiction. Gender and aim of Internet use explain $2.5 \%$ and $1.6 \%$ unique variance in predicting Internet addiction, respectively. To sum up, students who spend more time on the Internet and social media, who are male, and who use Internet for communication are more likely to have higher Internet addiction scores.

Table 10. Regression Table (IV: Personal Data DV: Internet Addiction)

\begin{tabular}{|l|l|l|c|c|c|}
\hline DV & \multicolumn{1}{|c|}{ Predictor(Uniqe $\left.\mathbf{R}^{\mathbf{2}}\right)$} & Beta & $\mathbf{t}$ & Sig. \\
\hline \multirow{4}{*}{$\begin{array}{l}\text { Internet } \\
\text { addiction }\end{array}$} & $\mathrm{x} 1$ & Time on Internet $\left(\mathbf{R}^{\mathbf{2}}=. \mathbf{1 6 2}\right)$ &, 33 & 4,54 &, 000 \\
\cline { 2 - 5 } & $\mathrm{x} 2$ & Time on Social media $\left(\mathbf{R}^{\mathbf{2}}=\mathbf{. 0 2 1}\right)$ &, 18 & 2,45 &, 015 \\
\cline { 2 - 5 } & $\mathrm{x} 3$ & Gender $\left(\mathbf{R}^{\mathbf{2}}=\mathbf{. 0 2 5}\right)$ & -16 & 2,50 &, 013 \\
\cline { 2 - 5 } & $\mathrm{x} 4$ & Aim of Internet use $\left(\mathbf{R}^{\mathbf{2}}=\mathbf{. 0 1 6}\right)$ & $-2,05$ &, 041 \\
\cline { 2 - 5 } & $\mathrm{R}=.473, \mathbf{R}^{\mathbf{2}}=. \mathbf{2 2 4}, \mathrm{F}(4,204)=14.70, \mathrm{p}<.001$ & \multicolumn{2}{|l}{} \\
\hline
\end{tabular}

Second, the effects of social media memberships on Internet addiction were tested. Due to sample size limitations between Facebook, Badoo, and Yonja members and not members, they were not included in the analysis. Twitter, YouTube, Pinterest, MySpace, Linkedln, and Hocam were determined as independent variables. Only significant regressions were reported in Table 11. Linkedln and YouTube memberships are significant predictors of Internet addiction. Linkedln membership explains $6.4 \%$ variance and YouTube membership explains $2.7 \%$ variance in Internet addiction. It appears that Linkedln and YouTube memberships predict Internet addiction as well as PsyCap.

Table 11. Regression Table (IV's: Personal Data DV: Internet Addiction)

\begin{tabular}{|l|l|l|l|l|l|}
\hline DV & \multicolumn{1}{|c|}{ Predictor(Uniqe $\left.\mathbf{R}^{2}\right)$} & Beta & t & Sig. \\
\hline \multirow{3}{*}{ Internet addiction } & $\mathrm{x} 1$ & Linkedln $\left(\mathbf{R}^{\mathbf{2}}=. \mathbf{0 6 4}\right)$ &,- 23 & $-3,47$ &, 001 \\
\cline { 2 - 6 } & $\mathrm{x} 2$ & YouTube $\left(\mathbf{R}^{\mathbf{2}}=. \mathbf{0 2 7}\right)$ &,- 17 & $-2,48$ &, 014 \\
\cline { 2 - 6 } & $\mathrm{R}=.301, \mathbf{R}^{\mathbf{2}}=.091, \mathrm{~F}(2,206)=10.35, \mathrm{p}<.001$ \\
\hline
\end{tabular}


Why YouTube and Linkedln memberships are significantly associated with Internet addiction? The time spent on these technologies may be the reason for that. Therefore, the interactions of social media and Internet using time with Linkedln and YouTube were also analyzed. When Internet addiction is assigned as a dependent variable in analyses of variance, the associations between Linkedln and Internet using time $[F(2,203)=.102, p<.05]$, Linkedln and social media using time $[F(3,201)=1.13, p<.001]$ are significant. The interactions among YouTube membership and Internet and social media using time are not significant concerning Internet addiction. YouTube and aim of Internet use are significantly associated $[F(3,201)=1.13, p<$ .001]. Especially students having YouTube accounts and those who use Internet for communication ( $M=49.44)$ and entertainment/news $(M=41.39)$ have higher Internet addiction scores than students not having an account and using Internet for communication ( $M=45.25)$ and entertainment/news $(M=35.83)[F(3,201)=1.13, p<.001]$. Time spent on Linkedln is related to Internet addiction. The characteristics of YouTube may be the reason for Internet addiction.

\section{Discussion and Limitations}

This study investigated the role of Internet addiction, demographic variables, and types of social media membership on PsyCap in a sample of university students. A negative and significant correlation was found between Internet addiction and resilience factor of the PsyCap. Internet addiction scores were grouped into two categories, as Internet-addicted and not-Internet-addicted. When these groups are compared, the PsyCap of Internet-addicted students $(M=72.79, S D=11.03)$ are significantly lower than not-Internet-addicted students $(M=69.8, S D=11.33)$. Internet addicted students are more likely to have lower PsyCap scores. The sub-factors of PsyCap are resilience, hope, optimism, and self-efficacy. The resilience and the self-efficacy scores of Internet addicted students are significantly lower than not-addicted ones. The optimism and hope scores of the Internet addicted students are low but not significant compared to not-addicted students. It is generally known that pathological Internet use or internet addiction is associated with some variables like depression (Young \& Rogers, 1998), loneliness and shyness (Eroglu, Pamuk, \& Pamuk, 2013), lower self-esteem and less satisfaction with life (Spraggins, 2009). Decreased PsyCap associated with internet addiction is a new finding reported in the present study, which should be analyzed further from different perspectives.

Concerning demographic information, as Internet and social media using time increases, the Internet addiction increases. This is consistent with the literature. Individuals using Internet for communication are more likely to be Internet-addicted than those using Internet for entertainment/news. Durak-Batigun and Kilic (2011) reported that Internet using time and the reason for Internet using are signs of Internet addiction. Internet and social media using time is not significantly associated with PsyCap in this study. Rosas (2011) stressed that the internet usage for information and communication can produce both good and bad results. The reason for Internet addiction may be gratification of some needs like communication. As needs are fulfilled by social media and internet, negative results of addiction can be ignored.

PsyCap differ according to academic success, connection place to Internet, and having a blog. Students who connect to the Internet from cell phones, have higher academic success and attend blogs have higher PsyCap scores. Of these variables, connecting Internet from cell phone seemed not to be significant for its association with PsyCap. It may be the result of high 
socioeconomic status, less time on the Internet etc. Why blog owners had higher PsyCap? This may be interpreted in two ways. On the one hand, it is possible that individuals with higher PsyCap prefer having a blog. On the other hand, blogs could develop or restructure individual's inner state in a positive way. Hossain and Quinn (2012) evaluated students' responses to blog using. Almost all students find using blog collaborative, convenient, enjoyable, engaging, useful by getting feedback from others, safe and secured as well. Blogging means higher self disclosure of the feelings, thoughts, experiences, and information with others and more human network. Blogging improves social capital and subjective well-being. (Ko \& Kuo, 2009) These challenging properties of blogging can develop a kind of self- awareness and individuals' PsyCap.

Although social media using time does not interact with PsyCap, social media membership leaded to both higher PsyCap scores and higher Internet addiction scores. This is a complex result that required more attention and further discussion. Normally, Internet addiction and PsyCap negatively interacted. However, when the focus was directed to social media members it was observed that they were more addicted. Whereas the PsyCap's of social media members were higher than not users. Especially, PsyCap scores of the students, having Linkedln and YouTube accounts were significantly higher. Internet addiction scores were significantly higher of the students having Twitter, YouTube, Pinterest, and Linkedln accounts.

It could be said that, social media increases the likelihood of Internet addiction, but also increases PsyCap. LaRose, Mastro, and Eastin (2001) point out that although internet addiction has negative impact on psychological well-being, internet based activities can also support personal gratifications or positive outcomes like social interaction, fun, relaxing activities. Therefore, social media have both positive and negative effects on individuals. Social media gratify some needs including communication, being related, membership of a group entertainment etc. (Ballard, 2011). Song Eeh-eun (2011) state that individuals had two main motives in using Internet: motivating virtual identity and escaping from reality. Perhaps, internet addiction is related to escape from reality, whereas social membership can be correlated with motivating virtual identity. Escaping create a feeling of hopelessness, whereas social membership increases hope and fulfillment.

When the regression analyses are overviewed, PsyCap can be predicted by academic success, Internet addiction, having a blog and Internet connection from cell phone. To sum up, as Internet addiction increases, PsyCap decreases. Although using social media membership is a sign of Internet addiction, it increases PsyCap, too. For PsyCap, the type of social media is important due to the gratification of different needs. Communication, social support, feeling connected etc. are thought to lead to higher optimism, resilience, hope, and self-efficacy levels. Gyudong, Jaeeun, and Soonjae (2011) have proven that social media enable individuals to disclose their thoughts, feelings, and experiences. The amount of disclosure is important for the subjective well being, not the time spent on social media.

The interaction between Linkedln and hope is also significant. Individuals with higher levels of hope are more goal oriented (Peterson et al., 2011, p.430). Therefore, Linkedln and hope relations may be explained with the achievement concern and finding new ways for achieving the goals (Synder, 2000). Linkedln can be accepted as a tool that creates positive emotions in terms of attaining individual objectives. YouTube membership is associated with self efficacy and resilience. Self efficacy, conceptualized by Bandura (1997), is defined as the individual's belief in his/her own ability to mobilize. Compared to self efficacy, hope is a wider concept not focusing on certain skills or cases. Self efficacy might have been developed by social learning 
capabilities of YouTube. Resilience is related to taking action and adaptation to cases of uncertainty, conflict, failure, or even positive change. Resilience helps to maintain well-being even when the situation is stressful and/or challenging (Gallagher, 2009). Why YouTube and Linkedln members' PsyCap ascores re significantly higher should also be investigated. Whether the users already have high PsyCap levels or YouTube and Linkedln have an effect in increasing PsyCap scores remains a question to be enlightened.

Overall, it is clear that today's university students use the computer much more effectively compared to previous generations. That's why they are considered "digital natives", whereas their parents and teachers are seen as "digital immigrants". However, a new and serious problem arises: They have less computer anxiety for sure but they are getting more and more computer addicted (Simsek, 2011), which has a variety of negative effects on their wellbeing, psychological capital, happiness, and intellectual development. Social media applications make the situation even worse, although they seem to present more friendly environments as far as interfaces and interactions are concerned.

\section{References}

Akin, A. \& Iskender, M. (2011). Internet addiction and depression, anxiety and stress. International Online Journal of Educational Sciences, 3(1), 138-148

Azher, M., Khan, R.B., Salim, M., Bilal, M., Hussain, A., \& Haseeb, M. (2014). The relationship between internet addiction and anxiety among students of University of Sargodha. International Journal of Humanities and Social Science, 4(1), 288-293.

Ballard, L.C. (2011). “What's happening”@Twitter: A uses and gratifications approach (Unpublished master's thesis). University of Kentucky. Retrieved on 10 July 2014 from http://uknowledge.uky.edu /gradschool_theses/155

Bandura, A. (1997). Self-efficacy: The exercise of control. New York: W.H. Freeman and Company.

Bayraktar, F. \& Gun, Z. (2007). Incidence and correlates of internet usage among adolescents in North Cyprus. CyberPsychology \& Behavior, 10(2), 191-197.

Bayraktar, F. (2001). Internet kullaniminin ergen gelisimindeki rolu (Yayimlanmamıs yuksek lisans tezi). Ege Universitesi Sosyal Bilimler Enstitüsü. Izmir.

Cao, H., Sun, Y, Wan, Y, Hao, Y. \& Tao, f. (2011). Problematic Internet use in Chinese adolescents and its relation to psychosomatic symptoms and life satisfaction. $B M C$ Public Health, 11, 802.

Cash, H., Rae, C.D., Steel, A.H., \& Winkler, A. (2012). Internet addiction: A brief summary of research and practice. Curr Psychiatry Rev., 8(4), 292-298.

Cetin, F. \& Basim, H.N. (2011). Psikolojik dayanikliligin is tatmini ve orgutsel baglilik tutumlarindaki rolu. Is, Guc; Endustri Illiskileri ve Insan Kaynaklari Dergisi, 13(3), 79-94.

Cetin, F. \& Basim, H.N. (2012). Orgutsel psikolojik sermaye: Bir olcek uyarlama calismasi. Amme Idaresi Dergisi, 45(1), 121-137.

Chen, Z. \& Davey, G. (2009). Subjective quality of life in South China: A public survey. Social Indicators Research, 91(2), 243-258. 
Csikszentmihalyi, M. \& Nakamura, J. (2009). Psychological capital. In S. J. Lopez (Ed). The encyclopedia of positive psychology. Hoboken, NJ: Blackwell.

Cummins, R. A. (2000). Personal income and subjective well-being: A review. Journal of Happiness Studies, 1, 133-158.

DSM-IV, American Psychiatric Association (1994) Diagnostic and statistical manual of mental disorders: DSM-IV (4 ${ }^{\text {th }}$ ed.). [Internet]. Washington (DC): American Psychiatric Association. Retrieved on 14 April 2014 from http://www.psychiatryonline.com/ DSMPDF/dsm-iv.pdf

Durak-Batigun, A \& Kılıc, N. (2011). Internet bagimliligi ile kisilik ozellikleri, sosyal destek, psikolojik belirtiler ve bazi sosyo-demografik degiskenler arasindaki iliskiler. Turk Psikoloji Dergisi, 26(67), 1-10.

Eroglu, M., Pamuk, M., \& Pamuk, K. (2013). Investigation of problematic internet usage of university students with psychosocial levels at different levels. Procedia-Social and Behavioral Sciences, 103(26), 551-557.

Eynseck, H.J. (1995). Trait theories of personality. In S.E. Hampson \& M.A. Colman (Eds.), Individual differences and personality (p.40-50). New York: Longman.

Gallagher, K. (2009). The road to resilience. Retrieved on 14 April 2014 from http://kellygallagher.org/resources/AoW\%209\% 20Road \%20to\%20Resilience.pdf

Gyudong, L., Jaeeun, L., \& \& Soonjae, K. (2011). Use of social-networking sites and subjective well-being: A study in South Korea. CyberPsychology, Behavior \& Social Networking, 14(3), 15.

Hossain, M.M. \& Quinn, R.J. (2012). Advantages and disadvantages of using a blogging activity in a college Euclidean geometry course. International Journal of Computer Technology and Electronics Engineering (IJCTEE), 2(6), 1-7.

Keser-Ozcan, N. \& Buzlu, S. (2005). An assistive tool in determining problematic Internet use: Validity and reliability of the online cognition scale in a sample of university students. Journal of Dependence, 6(1), 19-26.

Kim,K., Ryub, E., Chonb, M.Y., Ja Yeun, E., Choic, S.Y. Seod, Bum J.S., \& Namd, W. (2011). Internet addiction in Korean adolescents and its relation to depression and suicidal ideation: A questionnaire survey. International Journal of Nursing Studies, 43(2), 185192.

Ko, H.C. \& Kuo, F.Y. (2009). Can blogging enhance subjective well-being through selfdisclosure? CyberPsychology \& Behavior, 12(1), 75-79.

Larose, R., Mastro, D., \& Eastin, M.S. (2001). Understanding Internet usage: A social-cognitive approach to uses and gratification. Social Science and Computer Review, 19(4), 395-413.

Luthans, F. \& Youssef, C.M. (2004). Human, social, and now positive psychological capital management: Investing in people for competitive advantage. Organizational Dynamics, 33(2), 143-160.

Luthans, F., Avolio, B.J., Avey J.B., \& Norman S.M. (2007). Positive PsyCap: Measurement and relationship with performance and satisfaction. Leadership Institute Faculty Publications (Paper 11). Retrieved on 10 July 2014 from http://digitalcommons.unl.edu/ leadershipfacpub/11. 
Luthans, F., Youssef, C.M. \& Avolio, B.J. (2007). Psychological capital: Developing the human competitive edge. Oxford, UK: Oxford University.

O'Brien, C.P. (2010). Commentary on Tao et al. (2010): Internet addiction and DSM-V. Addiction, 105(3), 565.

Orsal, O., Orsal, O, Unsal, A., \& Ozalp, S. (2012). Evaluation of internet addiction and depression among university students. Procedia-Social and Behavioral Sciences, 82(3), 445-454.

Ozcinar, Z. (2011). The relationship between internet addiction and communication, educational and physical problems of adolescents in North Cyprus. Australian Journal of Guidance and Counseling, 21(01), 22-32.

Peterson, S., Luthans, F. Avolio, B. Walumbwa, F., \& Zhang, Z. (2011). Psychological capital and employee performance: A latent growth modeling approach. Personnel Psychology, 64, 427-450

Pies, (2009). Should DSM-V designate "internet addiction" a mental disorder? Psychiatry, 6(2), 31-37.

Rosas, O. V. (2011). Types of Internet use, well-being and the good life: Ethical views from prudential psychology. Retrieved on 18 June 2014 from http://perso.fundp.ac.be/ ovrosasm/Chapter_15_Omar\%20 Rosas_GLiTA.pdf

Sally, L.P.M. (2006) Prediction of internet addiction for undergraduates in Hong Kong. )Unpublished degree's thesis). Baptist University, Hong Kong. Retrieved on 18 June 2014 from http://lib-sca.hkbu.edu. hk/trsimage/hp/ 03007154.pdf

Seligman, M.E.P. (2007). Gercek mutluluk. Kalici doyum potansiyelinizi gelistirmek icin yeni olumlu psikolojinin kullanilmasi. Ankara: HYB.

Seligman, M.E.P., Steen, T.A., Park, N. \& Peterson, C. (2005). Positive psychology progress: Empirical validation of interventions. American Psychologist, 60, 410-421.

Simsek, A. (2011). The relationship between computer anxiety and computer self-efficacy. Contemporary Educational Technology, 2(3), 177-187.

Song, Eeh-eun. (nd). The analysis of relations between subjective happiness and computer usage in South Korea. Retrieved on 24 June from http://ricas.ioc.u-tokyo.ac.jp/ aasplatform/achivements/pdf/2011_ab_song.pdf

Spraggins, A. (2009). Problematic use of online social networking sites for college students: Prevalence, predictors and association with well-being. (Unpublished doctoral dissertation). University of Florida, Gainesville, FL.

Synder, C.R. (2000). Handbook of hope: Theory, measures and applications. San Diego, C.A: Academic Press.

Xiuqin, H.,Huimin, Z., Mengchen, L., Jinan, W., Ying, Z., \& Ran, T. (2010). Mental health, personality, and parental rearing styles of adolescents with internet addiction disorder. Cyberpsychology, Behavior, and Social Networking, 13(4), 401-406.

Yang, S.C. \& Tung, C. (2004). Comparison of Internet addicts and non-addicts in Taiwanese high school. Computers in Human Behavior, 23, 79-96.

Young, K. S. \& Rogers, R. C. (1998). The Relationship between depression and internet addiction. CyberPsychology \& Behavior, 1(1), 25-28. 
Young, K.S. \& Rogers, R. (1997, April). Depression and its relationship with pathological Internet use. Poster presented at the $68^{\text {th }}$ annual meeting of the Eastern Psychological Association. Washington, DC.

Young, K.S. (1996). Internet addiction: The emergence of a new clinical disorder. Paper presented at the $104^{\text {th }}$ annual meeting of the American Psychological Association. Toronto, Canada.

Young, K.S. (1998). Internet addiction: The emergence of a new disorder. CyberPsychology and Behavior, 1(3), 237-244.

Young, K.S. (1999). Internet addiction: Symptoms, evaluation, and treatment. This article is reproduced from Innovations in Clinical Practice (Volume 17) by L. VandeCreek \& T.L. Jackson (Eds.), Sarasota, FL: Professional Resource Press.

Yuan, K., Qin, W., Wang, G., Zeng, F., Zhao, L., Yang, X., Liu, P., Liu, J., Sun, J., \& von Deneen, K.M. (2011). Microstructure abnormalities in adolescents with internet addiction disorder. PLoS One, 6(6).retrieved on 10 July 2014 from, http://www.ncbi.nlm.nih.gov/ pmc/articles/PMC3108989/

Correspondence: Jale Balaban Sali, Associate Professor, Faculty of Communication Sciences, Anadolu University, Yunus Emre Campus, Eskisehir, Turkey 